\title{
Nauczyć umierania. Tanatopedagogika na lekcjach języka polskiego w liceum na przykładzie literatury najnowszej
}

Według Zygmunta Freuda życiem człowieka rządzą dwa popędy: Eros i Tanatos. Jeden $z$ nich odpowiada za popędy życiodajne i zachowawcze, drugi zaś odnosi się do pragnień niszczących, destruktywnych ${ }^{1}$. Nie omawiając zbyt dokładnie tej koncepcji wiedeńskiego myśliciela, wspomnieć trzeba, że człowiek w swoim trwaniu żyje w napięciu między represjami i zakazami wynikającymi z zachowawczej siły Erosa, a wypieranymi przeciwnymi pragnieniami Tanato$\mathrm{sa}^{2}$. Zdecydowanie łatwiej opowiadać chyba uczniom o miłości przedstawianej wielokrotnie w różnych wariacjach w literaturze, także tej omawianej w szkole ${ }^{3}$. Śmierć - chociaż stanowi poza narodzinami jedyne uniwersalne doświadczenie każdego człowieka — często jest w praktyce szkolnej pomijana, przemilczana jako temat refleksji edukacyjnej ${ }^{4}$. Wydaje się, że ta unikowa strategia może być

${ }^{1}$ Por. P. Dybel, Dialog i represja. Antynomie psychoanalizy Zygmunta Freuda, Warszawa 1995; idem, Freuda sen o kulturze, Warszawa 1996, s. 168-172.

2 Por. $i$ bidem.

${ }^{3}$ Por. R. Jedliński, Między miłosierdziem a globalizacją. Aksjologiczne przestrzenie edukacji polonistycznej, Kraków 2010; idem, Językowy obraz świata wartości w wypowiedziach uczniów kończących szkołe podstawowa, Kraków 2000; U. Kopeć, Językowy obraz wartości w wypowiedziach licealistów (przyjaźn - miłość - nienawiść), Rzeszów 2008; eadem, Nauczyć wyrażania miłości. Problemy teoretyczne i praktyczne, [w:] Edukacja polonistyczna jako zobowiazane. Powszechność i elitarność polonistyki, red. E. Jaskółowa, D. Krzyżyk, B. Niesporek, Katowice 2016; Życie bez miłości jest (nie)możliwe. Aspekty nie tylko językowo-literackie, red. A. Kucharska-Babula, M. Bąk, U. Kopeć, Rzeszów 2019.

${ }^{4}$ Por. D. Incontri, F. Santana-Santos, Edukacja do życia i śmierci od szkoły podstawowej po uniwersytet, przeł. E. Budajczak, [w:] Ars moriendi, ars vivendi, ars educandi, red. Z. Rudnicki, Poznań 2012, s. 461-462. 
jeszcze bardziej widoczna w dzisiejszych czasach, gdy ludzkość dotknięta została pandemią koronawirusa. Doświadczenie śmierci - wcześniej może dalekie w perspektywie czasowej młodzieży — stało się niestety dużo bliższe, nierzadko zaś także boleśnie osobiste. Trwająca przecież wciąż epidemia spowodowała znaczne pogorszenie funkcjonowania psychicznego tak nastolatków, jak i dorosłych, co widoczne jest w postaci zaburzeń psychicznych o charakterze lękowym czy afektywnym ${ }^{5}$. Trudno na lekcjach — szczególnie języka polskiego - o umieraniu nie mówić, gdy codziennie w komunikatach rządowych informowani jesteśmy o liczbie Polaków zmarłych z powodu COVID-19.

Celem kształcenia językowego i literackiego w szkole nie może być bowiem wyłącznie nauczanie teoretycznej wiedzy o literaturze czy języku, ale także konfrontowanie, poprzez interpretację dzieł literackich, z ważnymi doświadczeniami, także tymi najtrudniejszymi, granicznymi ${ }^{6}$. Jak konstatuje Dariusz Szczukowski, „doświadczenie lektury powinno więc być przede wszystkim zetknięciem z czymś niepokojącym, dającym do myślenia, prowadzącym do rozmowy, którą poprzez obcowanie $\mathrm{z}$ tekstem literackim toczymy ze sobą"" . Lektura staje się w takim wypadku przestrzenią rozwoju osobowości, kształtowania się tożsamości młodego człowieka ${ }^{8}$. Rozwój jednostki nie może być oczywiście holistyczny, jeśli w trakcie inspirowanej lekturą szkolnej refleksji nie porusza się tematyki eschatologicznej czy tanatologicznej. Przedmiot ,język polski”, co najmniej teoretycznie, zgodnie z zapisami podstawy programowej, powinien być miejscem prowadzenia namysłu nad śmiercią i umieraniem ${ }^{9}$. Jednak treści takie pojawiają się stosunkowo rzadko, choć wedle wskazań uczniów właśnie lekcje literatury są dobrą przestrzenią na tego rodzaju rozmowy ${ }^{10}$.

Założenia tego artykułu mają zatem charakter dwojaki: literaturoznawczy i pedagogiczny, a właściwie: tanatopedagogiczny. Po pierwsze, celem niniejszego szkicu jest dokonana na użytek kształcenia literackiego na poziomie licealnym interpretacja dwóch tekstów literatury najnowszej: Rzeczy, których nie wyrzuciłem Marcina Wichy i Bezmatek Miry Marcinów. Oba utwory zostały bardzo dobrze przyjęte przez krytyków i otrzymały prestiżowe nagrody literackie: książka Wichy — nagrodę Nike (2018), natomiast utwór Marcinów - Paszport Polityki (2021).

Po drugie zaś, omówione teksty wpisane zostaną w program literackiego programu tanatopedagogiki. Nie chodzi bowiem tylko o to, aby teksty literackie,

${ }^{5}$ Por. M. Woźniak-Prus, M. Gambin, A. Cudo, Nastolatkowie wobec pandemii, https://covid. psych.uw.edu.pl/wp-content/uploads/sites/50/2021/03/Raport_nastolatkowie_wobec_pandemii.pdf (dostęp: 4.06.2021); J. Heitzman, Wptyw pandemii COVID-19 na zdrowie psychiczne, „Psychiatria Polska" 54, 2020, nr 2; A. Wojtczuk, Pandemia koronawirusa - zmiana w świecie. Zagrożenie dla zdrowia psychicznego i szanse rozwojowe, „Student Niepełnosprawny” 13, 2020, nr 20.

${ }^{6}$ Por. K. Koziołek, Czas lektury, Katowice 2017, s. 33-48.

${ }^{7}$ D. Szczukowski, Praktykowanie lektury, Gdańsk 2019, s. 32.

${ }^{8}$ K. Koziołek, op. cit., s. 136-143.

9 Por. E. Sielicka, Edukacja tanatologiczna w szkole, Szczecin 2017, s. 118-122.

${ }^{10}$ Por. ibidem, s. 150-151, 221-223. 
poświęcone tematyce śmierci, analizować i interpretować na lekcjach języka polskiego, lecz także sprawiać, by stawały się one narzędziem, dzięki któremu uczniowie będą mogli podjąć własną dojrzałą refleksję na tematy ostateczne.

\section{Tanatopedagogika literacka w liceum - kilka refleksji teoretycznych}

Trudno opowiadać — co najmniej pozornie — o śmierci nastolatkom. Kilkunastoletni młodzi ludzie przede wszystkim tworzą kolejne plany na przyszłość i starają się je realizować. Śmierć wydaje się daleką przyszłością, nieobecną w perspektywie czasowej licealisty. Nie oznacza to jednak, że uczniowie - nawet ci dużo młodsi - nie rozumieją procesu umierania swoich najbliższych. Jak pokazuje Elisabeth Kübler-Ross, jedna z najważniejszych badaczek tanatologii, nawet kilkuletnie dzieci mają świadomość tego, co dzieje się z ich umierającym rodzicem czy rodzeństwem i nie powinno się ukrywać czy zbytnio infantylizować tego faktu ${ }^{11}$. Nieodwracalność śmierci i jej ostateczność są w stanie zrozumieć już pięcioletnie dzieci ${ }^{12}$. Jak wskazują pedagogiczne analizy, z jednej strony, zaleca się, aby dziecko traktować poważnie, podmiotowo, z drugiej zaś: uniemożliwia mu się uczestnictwo w procesie odchodzenia, chociaż sama śmierć obecna jest niezwykle często w kulturze masowej ${ }^{13}$.

Doświadczenia tanatyczne - związane ze śmiercią osoby znaczącej dla jednostki — były udziałem większości gimnazjalistów i licealistów ${ }^{14}$. Tematyka tanatologiczna nie jest zatem uczniom obca czy niemożliwa do poznawczego zrozumienia. Dlaczego zatem tak rzadko pojawia się w ramach działań edukacyjnych? Być może pewnym wyjaśnieniem jest kwestia lęku przed śmiercią.

Lęk ten — by powrócić do początku niniejszego szkicu — można także opisać w kategoriach psychoanalitycznych jako walkę między pragnieniem życia a niemożliwą do pokonania śmiertelnością każdego $\mathrm{z}$ nas ${ }^{15}$. Trudno nie zgodzić się ze stwierdzeniem psychotanatologów twierdzących, że odczucie to jest immanentną i niewyzbywalną cechą każdego człowieka ${ }^{16}$. To oczywiście pojęcie nieostre, trudne do zdefiniowania i opisania (jak zresztą wiele zmiennych psychologicznych istniejących nie tyle obiektywnie, co tylko na poziomie konkretnych

${ }^{11}$ Por. E. Kübler-Ross, Życiodajna śmierć. O życiu, śmierci i życiu po śmierci, przeł. E. Stahre-Godycka, Poznań 1996, s. 7-31.

12 J. Binnebesel, Percepcja lęku przed śmiercia w kontekście Tanatopedagogicznej Relacyjnej Terapii Zastępczej, Toruń 2017, s. 68-70; J. Sztobryn-Bochomulska, Tanatos w literaturze dziecięcej $i$ jego pedagogiczny wymiar, Łódź 2020, s. 72-86.

13 J. Sztobryn-Bochomolska, op. cit.

${ }^{14}$ E. Sielicka, op. cit., s. 178-180.

15 Por. A. Widera-Wysoczańska, Rozmowy o przemijaniu. Hermeneutyczna analiza psychologiczna doświadczeń człowieka, Wrocław 2000, s. 18-20.

16 Ibidem, s. 38. 
zachowań czy odczuć). Zasadniczo wyróżnia się trzy aspekty lęku przed śmiercią: lęk przed śmiercią własną, lęk przed śmiercią osoby bliskiej oraz lęk przed samym procesem umierania ${ }^{17}$. Oczywiście człowiek stara się na różny sposób ten lęk opanowywać. Może to czynić poprzez stosowanie rozmaitych mechanizmów obronnych. Najbardziej znane z nich polegają na separowaniu się od zjawiska śmierci, unikaniu myślenia o przemijaniu czy symbolicznym używaniu eufemizmów do opisywania umierania ${ }^{18}$. Jak dowodzi teoria opanowania trwogi, lęk przed śmiercią można opanować poprzez identyfikację z normami światopoglądowymi i wysoką samoocenę $e^{19}$. Pewne mechanizmy radzenia sobie z lękiem tanatycznym wypracowała współczesna kultura — poczucie nieśmiertelności może dać zdominowanie dzisiejszego społeczeństwa przez „obsesję seksu”, potrzeba bliskości zrealizowana zostaje poprzez funkcjonowanie w społeczeństwach kolektywistycznych, a egzystencjalną pustkę mogą wypełnić gromadzone dobra materialne ${ }^{20}$. Przede wszystkim jednak $\mathrm{w}$ dzisiejszych społecznościach śmierć została zepchnięta na margines wspólnotowego doświadczenia. Przestała też istnieć jako fakt społeczny, a zmieniła się w kwestię medyczną, profesjonalną ${ }^{21}$. Usunięta ze społecznej codzienności stała się ,wyklęta”, zdziczała — jest czymś wstydliwym, nieporuszanym w rozmowach, nieobecnym w mediach czy kulturze masowej ${ }^{22}$. Opisane przed chwilą zjawiska kulturowe wskazują, jak ważne i doniosłe jest zadanie współczesnej tanatopedagogiki.

Czym właściwie jest tanatopedagogika? To stosunkowo młoda interdyscyplinarna subdyscyplina nauk pedagogicznych. Mówiąc metaforycznie, tanatopedagogika to „wychowanie do (współ)cierpienia, (współ)chorowania i (współ)umierania"23. Ponieważ samo umieranie jest procesem skomplikowanym i złożonym, to tanatopedagogika, jako gałąź pedagogiki, również czerpie z osiągnięć wielu dziedzin, jednak wielokierunkowe rozważania łączy zawsze pojęcie godności osoby ludzkiej24. Warto posłużyć się definicją Józefa Binnebesela, jednego z najważniejszych znawców tematyki tanatopedagogicznej w Polsce: „Tak więc tanatopedagogika jest nauką o wychowaniu ze świadomością śmiertelności wpisaną

${ }^{17}$ Por. J. Mesjasz, Klatwa czy dar przemijania? Studium z tanatopsychologii, Warszawa 2010, s. $66-67$.

18 Por. W. Łukaszewski, Udręka życia. Jak ludzie radza sobie z lękiem przed śmiercia, Sopot 2010, s. 38-42.

19 Ibidem, s. 53-57.

${ }^{20}$ Por. J. Mesjasz, op. cit., s. 40-46; A. Widera-Wysoczańska, op. cit., s. 39-42.

${ }^{21}$ Por. M. Ogryzko-Wiewiórowska, Desocjalizacja umierania. Aspekty socjologiczne kresu $\dot{z} y c i a$, [w:] Śmierć $i$ wiara $w$ życie pośmiertne $w$ świetle nauk przyrodniczych $i$ humanistycznych, red. M. Machinek, Olsztyn 2003.

22 J. Sztobryn-Bochomulska, op. cit., s. 39-46.

${ }^{23}$ P. Grzybowski, Praktyczne cele $i$ aspekty kształcenia tanatologicznego pedagogów i nauczycieli, [w:] Jak rozmawiać z uczniami o końcu życia i wolontariacie hospicyjnym, red. J. Binnebesel, A. Janowicz, P. Krakowiak, Gdańsk 2009, s. 8.

${ }^{24}$ Por. G. Godawa, Funkcjonowania rodziny dziecka objętego domowa opieka hospicyjna. Studium tanatopedagogiczne, Toruń 2016, s. 19-22. 
w naturę bytu ludzkiego, opartą na fundamentalnej zasadzie poszanowania godności każdej istoty ludzkiej oraz nienaruszalności i apriorycznej wartości każdego życia ludzkiego"25. Historycznie, w znaczeniu wąskim, tanatopedagogika odnosi się do pomocy osobom przeżywającym bezpośrednio doświadczenie śmierci stąd jej bliskie relacje z opieką hospicyjną czy medycyną paliatywną ${ }^{26}$. Wydaje się jednak, że rolą działalności tanatopedagogicznej w wymiarze praktycznym nie jest tylko interwencja kryzysowa w ostatnich chwilach życia dziecka czy rodzica, ale całościowe i ustawiczne wspieranie rozwoju osobowości jednostki poprzez uświadamianie i zwiększanie indywidualnego rozumienia jej własnej śmiertelności; tylko wtedy, żyjąc w perspektywie nieuchronności końca życia, można osiągnąc pełną i prawdziwą egzystencję ${ }^{27}$.

W takim właśnie - szerszym kontekście - będę wykorzystywał pojęcie tanatopedagogiki w niniejszym artykule. Moim podstawowym celem badawczym będzie odpowiedź na pytanie, jakie wartości tanatopedagogiczne - z perspektywy polonistyki szkolnej — da się odnaleźć w wymienionych powyżej lekturach, które można omówić jako teksty dodatkowe w liceum.

W literaturze skierowanej do młodego odbiorcy w ciągu ostatnich kilkudziesięciu lat można zaobserwować znaczące zmiany w podejściu do tematu odchodzenia - stanowisko mentorskie, pedagogiczne zostało zastąpione raczej personalnym, osobistym i podmiotowym towarzyszeniem w zagłębianiu się niedorosłego człowieka w tematykę eschatologiczną ${ }^{28}$. Poprzez odpowiedni język, utrzymywanie kontaktu z młodym czytelnikiem, wprowadzanie elementów humoru czy prostotę i szczerość przekazu współczesna literatura młodzieżowa oswaja i spokojnie wprowadza w rozważania o sprawach ostatecznych ${ }^{29}$. Niektóre $\mathrm{z}$ utworów mogą także pełnić funkcję terapeutyczną — umożliwiać pogodzenie się dziecka ze stratą bliskiej osoby i poradzenie sobie z traumatycznym doświadczeniem ${ }^{30}$. Analizę treści tanatologicznych we współczesnej literaturze dla dzieci i młodzieży oraz wskazanie możliwości ich wykorzystania w perspektywie tanatopedagogiki ukazała w swej interdyscyplinarnej publikacji Justyna Sztobryn-Bochomulska ${ }^{31}$.

Jednak w niniejszej pracy omówione zostaną utwory, które nie dotyczą bezpośrednio śmierci bohatera niedorosłego. $\mathrm{Z}$ jednej strony, umożliwić to może

25 J. Binnebesel, Tanatopedagogika $w$ doświadczeniu wielowymiarowości człowieka i śmierci, Torun 2013, s. 251.

${ }^{26}$ Por. J. Sztobryn-Bochomulska, op. cit., s. 58-72.

27 Ibidem.

${ }^{28}$ Por. A.M. Czernow, Przemiany motywu śmierci dziecka $w$ literaturze dla niedorostych, [w:] Śmierć w literaturze dziecięcej i młodzieżowej, red. K. Slany, Warszawa 2018.

${ }^{29}$ Por. B. Niesporek-Szamburska, Oswajanie przemijania - śmierć we wspótczesnej literaturze dziecięcej i młodzieżowej, [w:] Literatura dla dzieci i młodzieży, t. 5, red. K. Tałuć, Katowice 2017.

30 Por. A. Józefowicz, Oswajanie z przemijaniem - temat śmierci we wspótczesnej literaturze dla dzieci. Terapeutyczne walory wybranych powieści, „Dziecko Krzywdzone. Teoria, Badania, Praktyka" 15, 2016, nr 3.

31 J. Sztobryn-Bochomulska, op. cit. 
uniwersalizację prowadzonych na lekcji rozważań, z drugiej zaś — trzeba pamiętać, że literatura o tematyce tanatologicznej, skierowana do dzieci i młodzieży, może okazać się zbyt prosta dla młodego dorosłego w liceum. Wydaje się jednak, że dzięki zastosowaniu odpowiednich strategii dydaktycznych utwory Wichy i Marcinów mogą być równie wartościowym materiałem pozwalającym na wprowadzenie do kształcenia literackiego w liceum elementów tanatopedagogiki. Cel będzie taki sam jak w przypadku podobnych utworów skierowanych do czytelnika niedorosłego: towarzyszenie we wspólnej refleksji nad skończonością ludzkiej egzystencji. W ten sposób refleksja wokół tematów ostatecznych prowadzona na lekcjach języka polskiego wpisywać się może w szeroko pojęte kształcenie humanistyczne pomagające $\mathrm{w}$ głębszym zrozumieniu własnego człowieczeństwa ${ }^{32}$.

Dlatego proponowany model lektury nie ma na celu strukturalistycznej analizy dzieła literackiego czy jego dekonstrukcji, lecz raczej opiera się na stworzeniu warunków do swobodnego dialogu z zawartą w literaturze mądrością; takie odczytanie wywodzące się z hermeneutycznej tradycji lektury pozwala także skupić się na kwestiach aksjologicznych poruszanych w książkach ${ }^{33}$. W jego centrum będzie przede wszystkim chęć zrozumienia egzystencji poprzez interpretację dzieła literackiego. Aby do tego mogło dojść, chciałbym w dokonywanej lekturze obu tekstów postarać się odpowiedzieć na trzy pytania: 1) jaki jest obraz śmierci i odchodzenia we współczesnej prozie polskiej; 2) jak można powiązać go z doświadczeniem uczniów; 3) jakie metody dydaktyczne można wykorzystać, by opowiadać o tematyce tanatologicznej w szkole, wprowadzając elementy tanatopedagogiki.

\section{Szczerze i bez patosu. Rzeczy, których nie wyrzuciłem Marcina Wichy}

Książka Marcina Wichy Rzeczy, których nie wyrzucitem może zaskakiwać, dziwić, a nawet - szokować. O doświadczeniu traumatycznym, niezwykle intymnym - śmierci matki - Wicha opowiada w sposób prosty, bezpretensjonalny, pozbawiony jakiegokolwiek patosu. Punktem wyjścia do egzystencjalnej refleksji w utworze są rzeczy, które pozostały narratorowi tekstu po jego zmarłej niedawno matce. Przemijanie wydaje się z początku tylko pobocznym tematem tego specyficznego eseju. W otwarciu tekstu przeczytać można następującą odautorską uwagę: „To jest historia o rzeczach. I jeszcze o gadaniu. Czyli — o słowach i przedmiotach. Jest to także książka o mojej matce i z tego powodu nie będzie zbyt wesoła" ${ }^{34}$. Żadnej śmierci, odchodzenia, funeralnej symboliki, żałobnych

32 Por. A. Zamarian, Edukacja ku dojrzałej recepcji fenomenu śmierci. Humanistyczny wymiar edukacji tanatologicznej, „Studia z Teorii Wychowania” 2015, $\mathrm{nr} 4$ (13).

${ }^{33}$ Por. B. Myrdzik, Zrozumieć siebie i świat. Szkice i studia o edukacji polonistycznej, Lublin 2006, s. 84-87.

${ }^{34}$ M. Wicha, Rzeczy, których nie wyrzuciłem, Kraków 2017, s. 5 (dalej: RKW, po przecinku numer strony). 
zdań. Wicha wprowadza czytelnika w temat śmierci oraz jego własnej relacji z matką niejako przy okazji, snując opowieści o jej mieszkaniu, książkach czy gromadzonych kompulsywnie przedmiotach. Gdzieś obok pojawiają się refleksje o trudnej rodzinnej historii, żydowskiej tożsamości, skrywanych przez pokolenia tajemnicach... Tworząc ten specyficzny portret kobiety, Wicha stara się jednocześnie matkę - a chyba także trochę siebie — zrozumieć. Spróbować zrekonstruować tożsamość.

Nie jest to przy tym opowieść sakralizująca matkę bohatera - narrator zdaje sobie sprawę z jej wad, trudnego charakteru, licznych przywar. Doskonale widać to w humorystycznym fragmencie wspomnień, gdy opisywana jest jej zdolność do kłócenia się i robienia awantur:

Najlepsze awantury urządzali we dwoje. Matka emocjonalna. Zaangażowana, na granicy histerii. Ojciec zdystansowany. Razem osiągali mistrzostwo. Matka w ataku. Ojciec ubezpieczał tyły. Na pozór niezaangażowany w rozgrywającą się scenę, gotów wskoczyć do akcji i służyć pomocą, imitując drugą, niby bezstronną opinię. (RKW, 105)

Ten brak patosu sprawia, że wspomnieniowa opowieść Wichy ujmuje swoją prawdziwością oraz szczerością. Pozostawione rzeczy, tkwiące w likwidowanym mieszkaniu rodziców, są być może w istocie figurami nowoczesnej żałoby, pozostałościami po zmarłych, które pozwalają ukoić ból po stracie i dać nadzieję na wieczność, gdy nie ma jej już w zlaicyzowanym społeczeństwie. To specyficzne exegi monumentum Wicha zamyka w lapidarnej formule: „Nie znikniemy bez śladu. A nawet jak znikniemy, to zostaną nasze rzeczy, zakurzone barykady” (RKW, 12). Następująca w kulturze ponowoczesnej „prywatyzacja śmierci” sprawia, że przeżywanie żałoby — także w literackich świadectwach — staje się kwestią intymną, osobistą, pozbawioną publicznego i religijnego wymiaru ${ }^{35}$. Może ono odbywać się w ramach porządkowania przedmiotów, a tak naprawdę: porządkowania pamięci. Wspomnieniowe strategie Wichy dalekie są jednak od mityzujących opowieści rodem z dwudziestolecia międzywojennego czy rozliczeniowych konfesji, niczym w Całym życiu Sabiny Heleny Boguszewskiej (warto zauważyć podobieństwo między książką Wichy i powieścią Boguszewskiej oba utwory łączą tematykę przemijania z „pamięcią rzeczy”). Pamięć — choćby ta tkwiąca w przedmiotach, anegdotach, ironicznych historyjkach — pozostaje w czyimś życiu. I chociaż w przenikliwym eseju Łukasz Najder konstatuje:

Rzeczy, których nie wyrzuciłem to znakomita, przejmująca książka o tym, że po wszystkim nie zostaje nazbyt wiele, choć może się wydawać, że bliskość, wspólne doświadczenia, ta sama krew i mieszkanie wypełnione przedmiotami gwarantują jakąś solidną formę trwania po śmierci. Nic bardziej mylnego. Są pojedyncze rzeczy, ulubiona książka i błyski w zupełnym mroku, które bierzemy za pamięćc ${ }^{36}$,

35 Por. O. Derewiecka, Oswajanie śmierci w literaturze współczesnej na podstawie „Umart mi. Notatnik żałoby” Ingi Iwasiów, „Studia Slavica” 24, 2020, nr 2.

${ }^{36}$ Ł. Najder, Nie wszystko o mojej matce, „Dwutygodnik”, https://www.dwutygodnik.com/ artykul/7191-nie-wszystko-o-mojej-matce.html (dostęp: 12.06.2021). 
to wydaje się, że już sama pisarska praca Wichy świadczy o tym, że jakaś pamięć — ulotna, niedoskonała, lecz szczera i przejmująca — jest możliwa.

To opowieść nie tylko o pamięci i o tym, co pozostaje, lecz także o umieraniu — przerażającym, niehumanitarnym, anonimowym. Językowa ironia, przenikliwa złośliwość są być może mechanizmem obronnym bohatera, który zmaga się z traumą:

— Wie pani — zaczynam — ja też jestem zwolennikiem eutanazji...

(Brak reakcji).

- ...ale czy musimy zaczynać od mojej matki?

(Brak reakcji). (RKW, 160)

Nie drgnęła jej powieka, kiedy chciała odesłać chorą, jednak krępuje się powiedzieć: ,ppana matka umiera". Ojczyzna-polszczyzna. W kraju zdrobnień można żywego człowieka potraktować jak truchło, ale koniecznie trzeba dodać „mama”, „mamusia”. (RKW, 161)

Mimo szpitalnego zinstytucjonalizowanego odchodzenia matka narratora umiera w spokoju, w swoim domu i przy dźwiękach powtarzanego niczym mantra zaklęcia: „Wszyscy cię kochają” (RKW, 178).

To też chyba jakaś nadzieja.

\section{Refleksja tanatopedagogiczna (I)}

Jakie znaczenia tanatopedagogiczne może mieć dla dzisiejszego licealisty omówiona powyżej lektura? Przede wszystkim doświadczenie okołotanatologicznego przeżycia jest autentyczne - refleksje o niewyrzuconych książkach, pozostawionych notatkach, zapomnianych rupieciach i tkwiącym jeszcze w powietrzu połączeniu wifi bliższe są z pewnością dzisiejszemu dojrzewającemu człowiekowi niż renesansowe figury śmierci w Trenach Jana Kochanowskiego. Można też zauważyć, że przedstawiane w lekturach szkolnych obrazy śmierci są zasadniczo nadzwyczajne (albo co najmniej: niezwyczajne) - umiera małe dziecko (Urszulka), rycerski bohater (Roland), poświęcająca się społeczeństwu nauczycielka (Siłaczka). W życiu jednak częściej niż ze śmiercią dramatyczną, niespodziewaną spotkamy się z odchodzeniem naturalnym - umrą na początku nasi starzy dziadkowie, a potem rodzice. Dlatego też ukazany w książce Wichy obraz śmierci i żałoby jest bardziej naturalny, życiowo prawdopodobny. Warto zatem zaprojektować lekcję polskiego poświęconą Rzeczom... jako intymne spotkanie mówiące o tym, co nas czeka, co nieuchronne i nieodwołalne...

Jeśli nauczyciel ma dobry kontakt z uczniami, a ci w jego towarzystwie czują się bezpiecznie, może zapytać wychowanków o ich doświadczenia związane z przeżyciami tanatologicznymi. Oczywiście tego rodzaju rozmowy powinny być prowadzone niezwykle delikatnie, a biorący w nich udział wychowankowie winni mieć zapewnioną atmosferę intymności oraz poufności. Warto, aby podczas takiego spotkania nauczyciel posługiwał się tak zwanym ,terapeutycznym stylem" pedagogicznej komunikacji, zwracającym uwagę przede wszystkim na 
podmiotowość ucznia ${ }^{37}$. Bez wątpienia lekcja języka polskiego nie może stać się formą grupowej terapii, więc osobiste doświadczenia młodych ludzi powinny stać się tylko punktem wyjścia do dalszej, kulturowej czy antropologicznej, refleksji. Wydaje się, że mogłoby być to miejsce na refleksję o samotności szpitalnego odchodzenia, zmianie form żałoby czy desocjalizacji umierania (szczególnie widocznej w trakcie pandemii koronawirusa). Z drugiej strony, we współpracy z psychologiem szkolnym można, przy okazji omawiania lektury, przygotować program profilaktyczno-terapeutyczny dotyczący wsparcia młodych osób w żałobie ${ }^{38}$.

Jeszcze inną kwestią, którą można poruszyć na lekcji języka polskiego, jest sprawa języka. Jak wskazują analizy dyskursu o śmierci, metaforyzacja języka, którym opowiada się o sprawach ostatecznych, sprawia nierzadko, że doświadczenie graniczne zostaje nieopowiedziane, zafałszowane, ukryte ${ }^{39}$. Prostota narracji Wichy może mieć funkcję oswajającą — przybliża ona tak czytelnika, jak i przeżywający podmiot opowieści do faktu odchodzenia i staje on się tym samym bliższy, naturalny, ,udomowiony” ${ }^{40}$. Rezygnując z funeralnej metaforyki i wzniosłych formuł, współczesny prozaik proponuje ironiczną i szczerą konfesję człowieka dotkniętego śmiercią najbliższej osoby. Opowieść Wichy nie jest z pewnością literackim nekrologiem wypełnionym pochwalnymi charakterystykami zmarłej, wyrazami żalu i uczuciowymi zdrobnieniami ${ }^{41}$. Tak jak w nekrologach, w Rzeczach... ważną rolę odgrywa wartościowanie, jednak nie jest ono, jak w przypadku funeralnych tekstów użytkowych, wyłącznie pozytywne, lecz ma na celu stworzenie prawdziwego, pełnego obrazu osoby zmarłej ${ }^{42}$. Takie odkonwencjonalizowane mówienie o osobie zmarłej może spowodować, że po lekturze utworu Wichy uczniowie odnajdą własny — autentyczny, a nie szablonowy i sztampowy — sposób mówienia o sytuacjach granicznych. I być może pozwoli im to na łatwiejsze przeżycie straty, która z pewnością będzie ich kiedyś czekać w życiu.

\section{Śmierć matki, żałoba i strata. Bezmatek Miry Marcinów}

Bezmatek Miry Marcinów to trudna i wymagająca dla czytelnika książka. I nie chodzi tutaj tylko o temat - umieranie najbliższej osoby, matki, ale także o kształt utworu. Literacki debiut krakowskiej badaczki historii psychologii przy-

${ }^{37}$ Por. A. Włodarczyk, Styl terapeutyczny nauczyciela-polonisty, Kraków 2007.

${ }^{38}$ Por. program profilaktyczno-terapeutyczny przygotowany przez Fundację Hospicyjną, http:// www.tumbopomaga.pl/images/pdf/PDF_Mlodziez_a.pdf (dostęp: 13.06.2021). Ten temat chcieliby podejmować uczniowie; por. E. Sielicka, op. cit., s. 224-225.

${ }^{39}$ Por. P. Szejnach, Trudne umieranie. Narracyjne przedstawienia choroby $i$ śmierci a doświadczenia osób terminalne chorych, Warszawa 2015, s. 76-81.

40 Por. ibidem, s. 82-84.

${ }^{41}$ Por. M. Jakosz, Polskie nekrologi w prasie - sposoby wartościowania językowego (na przyktadzie „, Gazety Wyborczej”), „Postscriptum Polonistyczne” 6, 2010, nr 2.

42 Ibidem. 
pomina raczej swobodny notatnik aniżeli ustrukturyzowany gatunek literacki. Ponowoczesne pisanie o stracie nie daje się zamknąć w schematyczną formę prozatorskiego trenu, wspomnienia czy elegii. Ucieczka Marcinów - jak innych współczesnych autorów piszących o przemijaniu — od funeralnych konwencji sprawia, że centralnym elementem opowieści staje się nie śmierć sama, lecz kończąca się (a może raczej: zmieniająca się?) relacja matki z córkąa ${ }^{43}$.

Opowieść ta z początku - podobnie jak u Wichy — nie dotyczy śmierci bezpośrednio, a samej codzienności życia z matką. O ile jednak w Rzeczach... narrator zdaje się zdystansowany, racjonalny, to w utworze Marcinów figura bliskości - a właściwie jej poszukiwania — odgrywa bardzo ważną rolę ${ }^{44}$. Czasami jedynym sposobem jej stworzenia jest wspólne marzenie o lepszej przyszłości:

Albo to był jakiś przelew, który nigdy nie dotarł. Pamiętam ten spacer z walizkami po wielkie zakupy. Pamiętam, jak na mnie patrzy smutna przy okienku na poczcie. Wracałyśmy z pustymi, sflaczałymi torbami. Imponowało mi, że pozwalała nam marzyćc ${ }^{45}$.

Świat w książce Marcinów jest także wiernym obrazem rzeczywistości końcówki PRL-u i początków polskiego kapitalizmu. To przestrzeń biedy, trudności materialnych, ale także czasów wielkiego szczęścia, gdy udało się matce głównej bohaterki założyć firmę i przez krótki czas żyć na wysokim poziomie materialnym. W opisach smutnej realności minionych czasów przebija pragnienie lepszego świata, a może także: lepszej miłości.

Sama robiła pasztet z kurzych skór. Jak je dostawała za darmo w mięsnym, mówiła ekspedientce, że to dla psa. Ale dla jej suczki były kurze łapy. Skóry były dla nas. Uwielbiałam ten pasztet.

Kanapki z pasztetem zrobiłam wam na drogę.

Tylko iść nie było gdzie. (B, 34)

I być może to jest właśnie główny temat tekstu: miłość, nieidealizowana, często toksyczna, uzależniająca. Tak zresztą opisuje swoją książkę w jednym z wywiadów sama autorka ${ }^{46}$. Jak pisze we wspomnieniu narratorka: „Matka była źródłem mojej największej przyjemności. I moich największych przykrości” (B, 75). Proces umierania matki jest tak naprawdę także procesem umierania córki, części jej tożsamości — bo figury te funkcjonują w umyśle narratorki w pewnej symbiozie ${ }^{47}$. Jak pisze w innym miejscu: „Matki nie odchodzą. Nie od córek. Może od synów odchodzą? [...] Ode mnie nigdy nie odeszła. Tylko umarła mi. Matka umarła" $(\mathrm{B}, 128)$. Literacki portret relacji matki i córki jest niezwykle poruszający, czasem wręcz szokujący, szczególnie w obrazie samego umierania.

43 Por. H. Serkowska, Ojciec odchodzi, „Autobiografia” 4, 2015, nr 1.

44 Por. S. Góra, Matki nie odchodzą. O książce ,Bezmatek” Miry Marcinów, „Kultura Liberalna" 2021, nr 663, https://kulturaliberalna.pl/2021/02/23/sylwia-gora-recenzja-bezmatek-mira-marcinow/ (dostęp: 15.06.2021).

${ }^{45}$ M. Marcinów, Bezmatek, Wołowiec 2020, s. 21-22 (dalej: B, po przecinku numer strony).

46 Por. Matki nie odchodza. Rozmowa z Mirą Marcinów [Z. Zaleska], „Dwutygodnik”, https:// www.dwutygodnik.com/artykul/8860-matki-nie-odchodza.html (dostęp: 15.06.2021).

47 Por. S. Góra, op. cit. 
W innym miejscu można przeczytać, że ,znużenie tym umieraniem jest nie do wytrzymania. Nuda, nuda, nuda. Umiera z nudów" (B, 130), kiedy indziej zaś córka próbuje jak najlepiej zorganizować ostatnie dni życia swojej matce, zapewnić jej komfort, przekonać do zaakceptowania samej siebie. Z niezwykle realistycznych opisów onkologicznego umierania i naturalnego przecież zmęczenia chorobą przebija niezwykle silna, uzależniająca wzajemna miłość. Z drugiej strony, opis ostatnich chwil życia matki zachwyca wręcz literacką głębią, rozbudowaną metaforyką i symboliką:

Przytrafiają nam się chwile ciszy, pełne czułości, pocałunków, głaskania, muskania. Nie wiem, co robię, nigdy przecież tego nie robiłam, a moja mama wilczyca umiera. Ostatnia godzina jej życia [...]. Ostatnie dwa, trzy oddechy są już tak rzadkie, że dzieli je minuta. Ostatni głęboki wydech. Gdy spoglądam na zegarek, jest trzecia czterdzieści pięć. Mama jest wciąż ciepła. Serca już nie słyszę, za to tętno na nadgarstku wyczuwam jeszcze długo. Do czwartej tak siedzę z jej wąskim i gładkim przegubem pod palcami. Jest cicho. (B, 139)

Pozostaje jeszcze żałoba — próba poradzenia sobie ze stratą. W przypadku bohaterki-narratorki polega to z początku na próbie mechanicznego wykonywania pogrzebowych rytuałów, wcześniej jeszcze na rozpaczliwej chęci ogrzania się w matczynym cieple w przejmującym fragmencie o przytulaniu się do ciała zmarłej kobiety. Wraz z upływem czasu bohaterka zatapia się w surrealistycznych fantazjach, gdy wyobraża sobie spotkanie martwych matek, które umarły naturalnie (co porównuje do naturalnego porodu), lub zastanawia się, jak śmierć jej matki opisałyby tabloidy. Okazuje się jednak, że do scharakteryzowania jej stanu psychicznego najlepiej pasuje formuła tytułowego „bezmatka” — sytuacji, gdy pszczeli ul pozbawiony jest matki-królowej i zaczyna dążyć do autodestrukcji. Trzeba wówczas poradzić sobie ze śmiercią matki, czyli — jak wcześniej zaznaczono - własną. A także z jej wiecznym trwaniem. Na koniec tej pobieżnej analizy dwa fragmenty książki.

Byłam córką samotnej matki. Na tym budowałam swoją tożsamość. To była moja główna rola. A że drugoplanowa - trudno. Przynajmniej stabilna, tak mi się wydawało. Byłam córką matki. I dlatego ta utrata tożsamości tak bardzo boli. Że oto jest szansa, by zobaczyć się jako ktoś inny, ktoś więcej niż córka? Wątpię. Jestem kimś mniej. (B, 210)

O tym, że moja matka jest nieśmiertelna, dowiedziałam się dopiero po jej śmierci. I skąd to niby miałam wiedzieć? Że matki będzie więcej teraz i tak naprawdę nigdy nie umrze. I skąd to miałam wiedzieć? (B, 245)

\section{Refleksja tanatopedagogiczna (II)}

W perspektywie tanatopedagogiki na pewno Bezmatek wykorzystać jest trudniej niż utwór Wichy. Z pewnością fragmenty dotyczące seksu czy zawierające wulgaryzmy mogą okazać się w warunkach szkolnej polonistyki zbyt kontrowersyjne. Natomiast to, co może być szczególnie interesujące w kontekście lekcji 
języka polskiego, to przedstawiona w książce wyjątkowa żałobna relacja matki z córką. Choćby w zestawieniu z niezwykle oszczędnym i nieemocjonalnym stylem Wichy opowieść Marcinów zachwyca swoją intensywnością. Ciekawym zabiegiem może być porównanie „męskiego" i „kobiecego” stylu literackiego przeżywania śmierci najbliższej osoby. Obok przykładu oczywistego - czyli Trenów Kochanowskiego, tomu Matka odchodzi Tadeusza Różewicza czy cyklu poetyckiego Anka Władysława Broniewskiego — przywołać można wykorzystywane w podręcznikach poruszające fragmenty dziennika Karola Irzykowskiego dotyczące śmierci jego córki Basi czy współczesny tekst Ingi Iwasiów Umarł mi o śmierci ojca pisarki ${ }^{48}$. Wydaje się, że taka komparatystyczna lektura mogłaby pomóc w analizie języka — zastosowanych środków stylistycznych, metaforyki czy refleksji o roli emocji w pisarskim oswajaniu doświadczenia utraty. Warto też wspólnie z uczniami zastanowić się nad rolą konwencji artystycznej — współczesne utwory nie są od niej tak uzależnione jak teksty wcześniejsze. Można podjąć namysł nad tym, czy uporządkowana struktura literacka pomaga, czy może utrudnia wyrażenie emocjonalnego cierpienia. Od kwestii formy przejść da się do sprawy języka - użytych wulgaryzmów, kolokwializmów czy słownictwa potocznego albo zapożyczeń z kultury masowej (piosenek, hasztagów). W tym kontekście przedyskutować warto z uczniami sprawę stosowalności w literaturze współczesnej zasady decorum przy przedstawianiu tematyki podniosłej.

Ostatnim aspektem — powiązanym ściśle z tanatopedagogiką — jest przeżywanie żałoby. Ukazany w trzeciej i czwartej części utworu Marcinów proces przeżywania straty zbliżony jest do stadialnego modelu żałoby zaproponowanego przez psychologów ${ }^{49}$. Korzystając z przywołanych już przy interpretacji książki Wichy materiałów pedagogiczno-psychologicznych, można uznać analizę utworu Marcinów za punkt wyjścia do dyskusji o wsparciu okazywanym osobom przeżywającym żałobę.

\section{Wnioski}

Przedstawiona powyżej refleksja nie ma na celu stworzenia całościowego ujęcia tematyki tanatopedagogicznej na lekcjach języka polskiego w liceum. Należy ją potraktować raczej jako metodyczną propozycję, zaproszenie do namysłu i dyskusji. Całościowy projekt wprowadzania elementów tanatopedagogicznych do programu przedmiotu ,język polski” wymagałby dalszych badań. Wydaje się jednak, że już dzięki tym wstępnym rozpoznaniom można wyciągnąć kilka interesujących wniosków.

48 Por. S. Rosiek et al., Między tekstami. Język polski. Podręcznik dla liceów i techników, cz. 2. Renesans. Barok. Oświecenie (echa wspótczesne), Gdańsk 2009, s. 116; E. Kraskowska, Ojcowska żałoba Karola Irzykowskiego, „Teksty Drugie” 2008, nr 5.

${ }^{49}$ Por. K. Ostoja-Zawadzka, Żałoba w rodzinie, [w:] Wprowadzenie do systemowego rozumienia rodziny, red. B. de Barbaro, Kraków 1999. 
Po pierwsze, odpowiednio interpretowana i omawiana na lekcjach języka polskiego literatura - szczególnie współczesna — może być dobrym narzędziem wprowadzającym w tematykę tanatologiczną, stając się punktem wyjścia do psychologicznej i antropologicznej refleksji o umieraniu.

Po drugie, warto zwrócić się na lekcjach języka polskiego ku literaturze najnowszej, która, nierzadko ze względu na nowoczesną formę i trudności interpretacyjne, bywa niesłusznie pomijana w szkole ${ }^{50}$. Wydaje się, że literatura taka mimo afabularnej konstrukcji i wymagającego dla licealisty języka może stać się, poprzez wspólnotę doświadczeń, nośnikiem ważnych i bliskich dla młodego człowieka sensów.

Po trzecie, trzeba pamiętać, że rozmowa o śmierci bardzo często może odwoływać się do trudnych osobistych doświadczeń i wzbudzać rozmaite emocje ${ }^{51}$. Warto, aby nauczyciel zdawał sobie sprawę z delikatności tego tematu i poruszał go w sposób ostrożny, empatyczny i szanujący podmiotowość ucznia. Tym bardziej ważne staje się psychologiczne przygotowanie nauczycieli polonistów, także pod kątem prowadzenia wspierających rozmów ze swoimi wychowankami.

I po czwarte wreszcie: należy zastanowić się nad wprowadzeniem do programu kształcenia nauczycieli edukacji tanatopedagogicznej. Jak wskazują badania, uczniowie nie uzyskują pomocy związanej z doświadczeniami tanatologicznymi od nauczycieli ${ }^{52}$. Sytuacja pandemii i wynikająca $z$ tego obecność śmierci w doświadczeniu społecznym, jak i osobistym sprawia, że kwestia ta jest jeszcze bardziej nagląca. Szczególnie ważną rolę odegrać mogą nauczyciele literatury — to rozmowy o bohaterach literackich i ich przeżyciach mogą stać się przyczynkiem do dyskusji o najważniejszych kwestiach — czekających każdego z nas sytuacjach ostatecznych.

\section{Bibliografia}

Binnebesel J., Percepcja lęku przed śmiercia w kontekście Tanatopedagogicznej Relacyjnej Terapii Zastępczej, Torun 2017.

Binnebesel J., Tanatopedagogika $w$ doświadczeniu wielowymiarowości człowieka i śmierci, Toruń 2013.

Czernow A.M., Przemiany motywu śmierci dziecka w literaturze dla niedorostych, [w:] Śmierć w literaturze dziecięcej i młodzieżowej, red. K. Slany, Warszawa 2018.

Derewiecka O., Oswajanie śmierci w literaturze współczesnej na podstawie „Umarł mi. Notatnik żałoby” Ingi Iwasiów, „Studia Slavica” 24, 2020, nr 2.

Dybel P., Dialog i represja. Antynomie psychoanalizy Zygmunta Freuda, Warszawa 1995.

Dybel P., Freuda sen o kulturze, Warszawa 1996.

Gozdawa G., Funkcjonowanie rodziny dziecka objętego domowa opieka hospicyjna. Studium tanatopedagogiczne, Toruń 2016.

${ }^{50}$ A. Janus-Sitarz, Kłopotliwi wspótcześni. Nieobecność nieusprawiedliwiona, [w:] Szkolna lektura bliżej teraźniejszości, red. A. Janus-Sitarz, Kraków 2011, s. 9-11.

${ }^{51}$ Por. P. Szejnach, op. cit., s. 303.

52 E. Sielicka, op. cit., s. 186-191. 
Góra S., Matki nie odchodzą. O książce „Bezmatek” Miry Marcinów, „Kultura Liberalna” 2021, $\mathrm{nr}$ 663, https://kulturaliberalna.pl/2021/02/23/sylwia-gora-recenzja-bezmatek-mira-marcinow/.

Grzybowski P., Praktyczne cele $i$ aspekty ksztatcenia tanatologicznego pedagogów i nauczycieli, [w:] Jak rozmawiać z uczniami o końcu życia $i$ wolontariacie hospicyjnym, red. J. Binnebesel, A. Janowicz, P. Krakowiak, Gdańsk 2009.

Heitzman J., Wpływ pandemii COVID-19 na zdrowie psychiczne, „Psychiatria Polska” 54, 2020, nr 2. Incontri D., Santana-Santos F., Edukacja do życia i śmierci od szkoły podstawowej po uniwersytet, przeł. E. Budajczak, [w:] Ars moriendi, ars vivendi, ars educandi, red. Z. Rudnicki, Poznań 2012.

Jakosz M., Polskie nekrologi w prasie - sposoby wartościowania językowego (na przykładzie „, Gazety Wyborczej”, „Postscriptum Polonistyczne” 6, 2010, nr 2.

Janus-Sitarz A., Kłopotliwi wspótcześni. Nieobecność nieusprawiedliwiona, [w:] Szkolna lektura bliżej teraźniejszości, red. A. Janus-Sitarz, Kraków 2011.

Jedliński R., Językowy obraz świata wartości w wypowiedziach uczniów kończących szkotę podstawowa, Kraków 2000.

Jedliński R., Między miłosierdziem a globalizacją. Aksjologiczne przestrzenie edukacji polonistycznej, Kraków 2010.

Józefowicz A., Oswajanie z przemijaniem - temat śmierci we wspótczesnej literaturze dla dzieci. Terapeutyczne walory wybranych powieści, „Dziecko Krzywdzone. Teoria, Badania, Praktyka" 15, 2016, nr 3.

Kopeć U., Językowy obraz wartości w wypowiedziach licealistów (przyjaźń - mitość - nienawiść), Rzeszów 2008.

Kopeć U., Nauczyć wyrażania miłości. Problemy teoretyczne i praktyczne, [w:] Edukacja polonistyczna jako zobowiazane. Powszechność i elitarność polonistyki, red. E. Jaskółowa, D. Krzyżyk, B. Niesporek, Katowice 2016.

Koziołek K., Czas lektury, Katowice 2017.

Kraskowska E., Ojcowska żałoba Karola Irzykowskiego, „Teksty Drugie” 2008, nr 5.

Kübler-Ross E., Życiodajna śmierć. O życiu, śmierci i życiu po śmierci, przeł. E. Stahre-Godycka, Poznań 1996.

Łukaszewski W., Udręka życia. Jak ludzie radzą sobie z lękiem przed śmiercią, Sopot 2010.

Marcinów M., Bezmatek, Wołowiec 2020.

Matki nie odchodzą. Rozmowa z Mira Marcinów [Z. Zaleska], „Dwutygodnik”, https://www.dwutygodnik.com/artykul/8860-matki-nie-odchodza.html.

Mesjasz J., Kląwa czy dar przemijania? Studium z tanatopsychologii, Warszawa 2010.

Myrdzik B., Zrozumieć siebie i świat. Szkice i studia o edukacji polonistycznej, Lublin 2006.

Najder Ł., Nie wszystko o mojej matce, „Dwutygodnik”, https://www.dwutygodnik.com/artykul/ 7191-nie-wszystko-o-mojej-matce.html.

Niesporek-Szamburska B., Oswajanie przemijania - śmierć we wspótczesnej literaturze dziecięcej i młodzieżowej, [w:] Literatura dla dzieci i młodzieży, t. 5, red. K. Tałuć, Katowice 2017.

Ogryzko-Wiewiórowska M., Desocjalizacja umierania. Aspekty socjologiczne kresu życia, [w:] Śmierć $i$ wiara $w$ życie pośmiertne $w$ świetle nauk przyrodniczych i humanistycznych, red. M. Machnik, Olsztyn 2003.

Ostoja-Zawadzka K., Żałoba w rodzinie, [w:] Wprowadzenie do systemowego rozumienia rodziny, red. B. de Barbaro, Kraków 1999.

Rosiek S., Grześkowiak R., Nawrocka E., Oleksowicz B., Między tekstami. Język polski. Podręcznik dla liceów i techników, cz. 2. Renesans. Barok. Oświecenie (echa współczesne), Gdańsk 2009.

Serkowska H., Ojciec odchodzi, „Autobiografia” 4, 2015, nr 1.

Sielicka E., Edukacja tanatologiczna w szkole, Szczecin 2017.

Szczukowski D., Praktykowanie lektury, Gdańsk 2019.

Szejnach P., Trudne umieranie. Narracyjne przedstawienia choroby i śmierci a doświadczenia osób terminalne chorych, Warszawa 2015. 
Sztobryn-Bochomulska J., Tanatos w literaturze dziecięcej i jego pedagogiczny wymiar, Łódź 2020. Wicha M., Rzeczy, których nie wyrzucitem, Kraków 2017.

Widera-Wysoczańska A., Rozmowy o przemijaniu. Hermeneutyczna analiza psychologiczna doświadczeń człowieka, Wrocław 2000.

Włodarczyk A., Styl terapeutyczny nauczyciela-polonisty, Kraków 2007.

Wojtczuk A., Pandemia koronawirusa — zmiana w świecie. Zagrożenie dla zdrowia psychicznego $i$ szanse rozwojowe, „Student Niepełnosprawny” 2020, nr 20 (13).

Woźniak-Prus M., Gambin M., Cudo A., Nastolatkowie wobec pandemii, https://covid.psych.uw.edu. pl/wp-content/uploads/sites/50/2021/03/ Raport_nastolatkowie_wobec_pandemii.pdf.

Zamarian A., Edukacja ku dojrzałej recepcji fenomenu śmierci. Humanistyczny wymiar edukacji tanatologicznej, „Studia z Teorii Wychowania” 13, 2015, nr 4.

Życie bez miłości jest (nie)możliwe. Aspekty nie tylko językowo-literackie, red. A. Kucharska-Babula, M. Bąk, U. Kopeć, Rzeszów 2019. 